\title{
PELAKSANAAN BAURAN PROMOSI PADA PRODUK BERAS UNTUK MENINGKATKAN OMZET PENJUALAN (STUDI PADA PT. NAZAR BAHANA PERSADA)
}

\author{
Merita Bernik \& Mochammad Bima Ramadhan \\ IFakultas Ekonomi dan Bisnis, Universitas Padjadjaran Bandung \\ E-mail: merita.bernik@unpad.ac.id
}

\begin{abstract}
Beras merupakan bahan pangan utama bagi penduduk Indonesia. Beragam jenis produk beras telah banyak dipasaran. Semakin beragamnya produk beras, maka diperlukan promosi yang dapat menginformasikan kelebihan suatu produk beras dibandingkan yang lainnya. PT. Nazar Bahana Persada merupakan salah satu perusahaan yang menghasilkan produk beras,akan tetapi masih menggunakan cara tradisional dalam memasarkan produknya. Untuk dapat bersaing maka PT Nazar Bahama Persada harus dapat memperbaiki stategi promosi yang dilakukan sehingga akan meningkatkan omzet penjualannya. Metode yang dipergunakan dalam penelitian ini adalah metode deskriptif yang akan memberikan gambaran mengenai pelaksanaan bauran promosi pada produk beras. Data yang dipergunakan adalah data primer melalui observasi dan wawancara serta data sekunder yang berupa dara yang diperoleh dari perusahaan. Bauran promosi yang dilaksanakan oeh PT Nazar Bahana Persada adalah personal selling, pemasaran langsung, periklanan dan juga melaksanakan CRS. Dampak promosi yang diterapkan oleh perusahaan terhadap penjualan produk beras pada tahun 2017 meningkat sebesar $44,75 \%$, sedangkan omzet penjualan meningkat sebesar $50,41 \%$.
\end{abstract}

Keywords: bauran promosi, omzet penjualan, strategi promosi, produk beras

\begin{abstract}
Rice is the main food for the population of Indonesia. Many types of rice products have been marketed. The more diverse rice products are, the more promotion is needed to inform the advantages of a rice product compared to others. PT. Nazar Bahana Persada is one of the companies that produce rice products, but still uses traditional methods of marketing their products. PT. Nazar Bahama Persada must be able to improve the promotion strategy carried out so that it will increase its sales turnover. The method used in this study is a descriptive method that will provide an overview of the implementation of the promotion mix on rice products. The data used are primary data through observation and interviews and secondary data in the form of virgin obtained from the company. The promotion mix implemented by PT Nazar Bahana Persada is personal selling, direct marketing, advertising and also implementing CRS. The promotional impact applied by the company to the sale of rice products in 2017 increased by $44.75 \%$, while the sales turnover increased by $50.41 \%$.
\end{abstract}

Keywords: promotion mix, sales turnover, promotion strategy, rice products 


\section{Merita Bernik}

\section{Mochammad Bima Ramadhan \\ PENDAHULUAN}

Terdapat berbagai jenis beras yang dihasilkan dari berbagai daerah, setiap jenis beras memiliki ciri tersendiri. Konsumen diberikan kebebasan untuk memilih dan memutuskan membeli beras sesuai dengan kebutuhan dan juga keiinginannya (Lontoh, 2016) . Berbagai macam beras yang ada dipasaran menyebabkan semakin meningkatnya persaingan antara para produsen beras. Jawa Barat erupakan salah satu dari 5 profinsi terbesar di Inonesai sebagai pengahsil beras terbesar di Indonesia. Hal tersebut dirasakan pula oleh PT Nazar Bahana Persada sebagai salah satu produsen beras di kota Garut. Bentuk pemasarannya yang masih bersifat konvensional atau tradisional yang menyebabkan perusahaan ini kalah bersaing.

Terdapat beberapa hal yang mempengaruhi pemasaran beras yaitu konsumen dan promosi. Promosi merupakan salah satu faktor penting dalam mewujudkan tujuan penjualan suatu perusahaan agar konsumen bersedia menjadi pelanggan. Konsumen terlebih dahulu harus dapat meneliti atau mencoba barang-barang yang diproduksi oleh perusahaan, akan tetapi konsumen tidak akan melakukan hal tersebut, jika kurang yakin terhadap suatu produk (Kotler \& Keller, 2016). Berdasarkan hal tersebut maka perlu dilakukan promosi yang terarah, karena diharapkan dapat memberikan pengaruh positif terhadap penjualan. Kondisi penjualan beras di kota Garut saat ini telah banyak perusahaan beras yang telah melaksanakan promosi secara modern, dengan harga yang lebih murah dan jumlah produksi yang banyak. Hal tersebut yang menyebabkan PT Nazar Bahana Persada harus merubah strategi bauran promosi produk berasnya, dan juga dengan menunjukan perbedaan beras yang dihasilkannya, Produksi baras di PT Nazar Bahana Persada terdiri dari tiga jenis beras unggulan yaitu: 1) Beras medium; 2) Beras premium; dan 3) Beras khusus. Berdasarkan hal tersebut di atas maka perlu dilakukan perbaikan bauran promosi yang dilaksanakan oleh PT Nazar Bahana Persada, serta dampak dari berubahan pelaksanaan bauran promosi tersebut dalam meningkatkan omzet penjualan beras.

\section{TINJAUAN LITERATUR}

Promotion Mix atau dikenal sebagai bauran promosi pemasaran memiliki enam mode komunikasi menurut Kotler dan Keller (2016) diantaranya adalah:

1. Iklan (Advertising) yaitu bentuk presentasi non personal dan promosi ide, barang, atau jasa oleh sponsor yang teridentifikasi melalui media cetak (koran dan majalah), media siaran (radio dan televisi), media jaringan (telepon, kabel, satelit, wireless), media elektronik (rekaman, rekaman video, disk video, CD-ROM, halaman web) dan media display (billboard, tanda - tanda, poster).

2. Promosi penjualan (Sales promotion) yaitu berbagai insentif jangka pendek untuk mendorong percobaan atau pembelian produk atau layanan termasuk promosi 
konsumen (seperti sampel, kupon, dan premi), promosi perdagangan (seperti iklan dan tunjangan display), dan bisnis dan tenaga penjualan promosi (kontes untuk tenaga penjual).

3. Acara dan pengalaman yaitu kegiatan yang disponsori oleh perusahaan dan program-program yang dirancang untuk membuat interaksi terkait dengan konsumen, seperti olahraga, seni, hiburan, dan serta kegiatan formal.

4. Hubungan masyarakat dan publisitas berbagai program yang ditujukan secara internal untuk karyawan perusahaan atau pihak eksternal kepada konsumen, perusahaan lain, pemerintah, dan media untuk mempromosikan atau melindungi citra perusahaan.

5. Pemasaran online dan media sosial yaitu aktivitas online dan program-program yang dirancang untuk pelanggan atau prospek yang dilakukan secara langsung atau tidak langsung untuk meningkatkan kesadaran, meningkatkan citra perusahaan, atau menimbulkan penjualan produk atau jasa.

6. Word Of Mouth (WOM) proses komunikasi yang berupa pemberian rekomendasi baik secara individu maupun kelompok terhadap suatu produk atau jasa yang bertujuan untuk memberikan informasi secara personal (Kennedy, 2014).

Promosi penjualan didefinisikan menurut Belch dan Belch (2013) adalah kegiatan pemasaran yang memberikan nilai ekstra atau insentif kepada tenaga penjualan, distribusi atau konsumen akhir dan dapat merangsang penjualan langsung.

Kotler dan Keller (2016) mengungkapkan promosi penjualan adalah berbagai insentif jangka pendek untuk mendorong percobaan atau pembelian produk atau layanan termasuk promosi konsumen (seperti sampel, kupon, dan premi), promosi perdagangan (seperti iklan dan tunjangan display), dan bisnis dan tenaga penjualan promosi (kontes untuk tenaga penjualan).

Adapula promosi penjualan yang diungkapkan oleh Cravens dan Piercy (2013) yaitu promosi penjualan adalah bentuk dari bujukan (kupon, kontes, dan potongan harga), kegiatan promosi dapat ditargetkan ke berbagai titik pengaruh dalam rantai nilai. Promosi penjualan yang digunakan oleh perusahaan bertujuan untuk merangsang penjualan langsung dan mendorong pembelian produk melalui alat-alat promosi penjualan yang dipilih perusahaan. Selain itu promosi penjualan merupakan bujukan dari berbagai alat promosi penjualan yang digunakan oleh perusahaan.

Menurut Cummins dan Mulin (2014) terdapat12 tujuan utama promosi yang ingin dicapai melalui promosi penjualan adalah meningkatkan vulve, meningkatkan pembelian cobacoba, meningkatkan pembelian ulang, meningkatkan loyalitas, memperluas kegunaan, 


\section{Merita Bernik}

\section{Mochammad Bima Ramadhan}

menciptakan ketertarikan, menciptakan kesadaran, mengalihkan perhatian dari harga, mendapat dukungan dari pelantara, menggunakan diskriminasi para pengguna, mengembalikan pesepsi brand, dan mempertahankan persepsi brand akibat kesalahan pelayanan. Beberapa tahapan promosi penjualan yang diungkapkan oleh Laksana (2013):

a. Menentukan Tujuan

b. Menyeleksi Ala-alat

c. Menyusun Program

d. Melakukan Pengujian Terhadap Promosi Penjualan

e. Melaksanakan dan Mengendalikan Program

f. Mengevaluasi Hasil

Ada empat metode untuk mengukur efektivitas promosi penjualan:

1. Memperbandingkan penjualan sebelum, sewaktu dan sesudah promosi.

2. Data panel konsumen akan mengungkapkan macam-macam orang yang menanggapi promosi penjualan dana yang mereka lakukan setelah promosi.

3. Survei konsumen apabila dibutuhkan banyak untuk mengetahui berapa banyak yang mengingat promosi, bagaimana pendapat mereka tentang promosi itu, dan bagaimana promosi tersebut mempengaruhi perilaku mereka dalam memilih merek produk.

\section{METODOLOGI}

\section{Jenis Penelitian}

Metode yang dipergunakan dalam penelitian ini adalah metoda deskriptif. Menurut Sakaran (2012) metode deskriptif adalah studi yang diberlakukan untuk mengetahui dan untuk menjelaskan karakteristik variabel yang diteliti dalam suatu situasi. Sehingga metode deskriptif ini mampu untuk menjelaskan dan memberikan gambaran karakteristik dari variabel yang diteliti sehingga dapat memecahkan permasalahan yang sedang dihadapi oleh PT Nazar Bahana Persada. Selain itu dalam penelitian ini juga menggunakan metode kuantitatif dimana akan dilakukan pengujian hipotesis untuk dapat membuktikan bahwa penerapan bauran promosi memiliki dampak pada omzet penjualan. Uji statistika non parametrik yang akan dipergunakan yaitu Wilcoxon test (Siegel,1988).

HO: $d=0$ (Omzet penjualan produk setalah dilaksanakan bauran promosi tahun 2017 sama dengan tahun 2016)

$\mathrm{H}$ 1: $\mathrm{d} \neq \mathrm{O}$ (Omzet penjualan produk setalah dilaksanakan bauran promosi tahun 2017 sama dengan tahun 2016). 
Dengan d menunjukkan selisih nilai antara kedua perlakuan.

$$
\mathrm{Z}=\frac{T-\left[\frac{1}{4 N(N+1)}\right]}{\sqrt{\frac{1}{24 N(N+1)(2 N+1)}}}
$$

Dimana :

$\mathrm{N}=$ Banyak data yang berubah setelah diberi perlakuan berbeda.

$T$ = Jumlah renking dari nilai selisih yng negative (apabila banyaknya selisih yang positif lebih banyak dari banyaknya selisih negatif).

= jumlah ranking dari nilai selisih yang positif (apabila banyaknya selisih yang negatif $>$ banyaknya selisih yang positif).

\section{Daerah kritis}

HO ditolak jika nilai absolute dari Z hitung diatas>nilai Z 2 / a

\section{Metode Pengumpulan Data}

Data yang dipergunakan adalah data primer dan data sekunder. Data primer diperoleh melalui observasi, wawancara yang dilakukan terhadap direktur, manajer dan bagian marketingperusahaan. Teknik sampling yang dipergunakan untuk melaksanakan wawancara adalah nonprobability sampling dimana yang menjadi sampel adalah orang yang memang paham dan menjalankan bauran promosi seperti direktur, manajer dan juga bagian marketing. Sedangkan data sekunder diperoleh dari data-data perusahaan seperti besarnya penjualan produk beras, pendapatan perusahaan dan juga omzet penjualannya. Data sekunder diperoleh berdasarkan data tahun 2016 (Januari-Desember) dimana pada tahun tersebut masih menggunakan bauran promosi tradisional, dan data tahun 2017 (Januari-Desember) dimana perusahaan telah menerapkan 4 jenis bauran promosi. Operasional variabel yang dipergunakan untuk melaksanakan wawancara berdasarkan pada bauran promosi dapat dilihat pada Tabel 1.

\section{Tabel 1. Operasional Variabel}

\begin{tabular}{|c|c|c|c|}
\hline No & Variabel & Dimensi & Indikator \\
\hline 1 & \multirow{6}{*}{$\begin{array}{c}\text { Bauran } \\
\text { Promosi (Kotler } \\
\text { dan Keller, } \\
2016 \text { ) }\end{array}$} & Iklan & Bentuk iklan yang dipergunakan \\
\hline 2 & & Promosi Penjualan & Jenis promosi penjualan yang dilakukan \\
\hline 3 & & Acara dan Pengalaman & $\begin{array}{l}\text { Bekerjasama dengan perusahaan lain } \\
\text { Sponsorship }\end{array}$ \\
\hline 4 & & $\begin{array}{l}\text { Hubungan masyarakat } \\
\text { dan publisitas }\end{array}$ & CSR yang dilakukan \\
\hline 5 & & $\begin{array}{l}\text { Pemasaran online dan } \\
\text { media social }\end{array}$ & $\begin{array}{l}\text { Jenis pemasaran online atau media } \\
\text { social yang dipergunakan }\end{array}$ \\
\hline 6 & & Word Of Mouth (WOM) & $\begin{array}{l}\text { Jenis promosi WOM yang } \\
\text { dipergunakan }\end{array}$ \\
\hline
\end{tabular}




\section{Merita Bernik}

\section{Mochammad Bima Ramadhan}

\section{Metode Analisis Data}

Data yang diperoleh dari hasil observasi dan wawancara tersebut kemudian dianalisis dan dibandingkan dengan data sekunder yang berupa data penjualan produk beras, dan omzet penjualan untuk diketahui dampaknya sebelum dan setelah melakukan perubahan startegi promosi yang dilakukan oleh PT Nazar Bahana Persada. Pada akhirnya dapat diperoleh bukti yang kongkrit bahwa bauran promosi yang dilakukan memiliki dampak kenaikan omzet penjualan beras.

\section{HASIL DAN PEMBAHASAN}

Jenis-jenis beras yang dihasilkan oleh PT Nazar Bahana Persada antara lain:

\section{Beras Medium}

Beras medium adalah beras yang tingkat kadar broken maksimal 14 persen. Kadar air ini ditentukan dari jumlah kandungan air di dalam butir beras. Beras medium memiliki butir patah atau beras pecah (broken) maksimal 20 persen untuk medium I, sedangkan untuk medium II maksimal 25 persen, dan medium III maksimal 35 persen. Berikut contoh produk beras yang di buat di PT. Nazar Bahana Persada sebagai berikut:

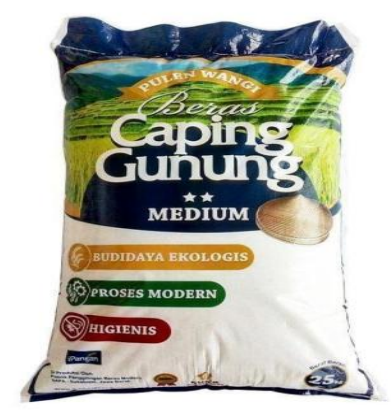

\section{Gambar 1. Beras Medium I}

(Sumber: foto produk PT. Nazar Bahana Persada beras medium I tahun 2016)

Beras medium II salah satu varian produk yang dibuat di PT. Nazar Bahana Persada yang mempunyai kadar air yang kurang dari $14 \%$, dan mempunya kadar atau berar pecah sebanyak $25 \%$. Beras medium III salah satu varian produk yang dibuat di PT. Nazar Bahana Persada yang mempunyai kadar air yang kurang dari $14 \%$, dan mempunya kadar atau berar pecah sebanyak $35 \%$.

\section{Beras Premium}

Syarat khusus beras yang dikategorikan premium diantaranya, derajat sosoh mencapai 100 persen. Derajat sosoh merupakan tingkat terlepasnya aleuron (kulit ari) yang melapisi biji beras. Selain itu, tingkat kadar air maksimal 14 persen. Kadar air ini ditentukan dari jumlah kandungan air di dalam butir beras. 
- Thailand White Rice 5\% Broken

- Vietnam White Rice 5\% Broken

- Pakistan White Rice 5\% Broken

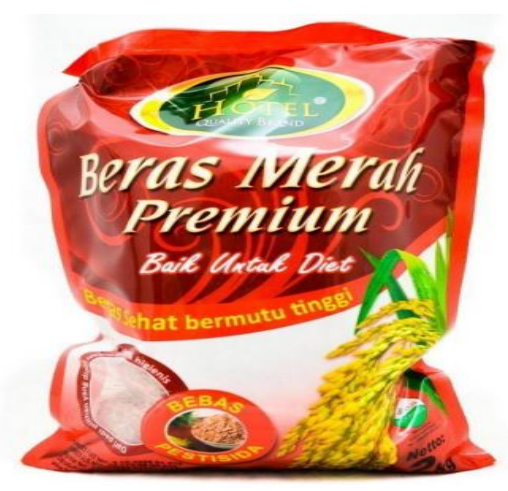

Gambar 2. Beras Premium I

(Sumber: foto produk PT. Nazar Bahana Persada beras premium I tahun 2016)

Beras premium II beras yang mengandung derajat sosoh 100 dan tingkat kadar air $14 \%$, dan mempunyai broken white $5 \%$ sama dengan beras yang berasal dari Vietnam. Beras premium III beras yang mengandung derajat sosoh 100 dan tingkat kadar air $14 \%$, dan mempunyai broken white $5 \%$ sama dengan beras yang berasal dari Pakistan.

\section{Beras Khusus}

Kriteria beras khusus yang disamakan dengan beras premium adalah derajat sosoh minimal 95\%, kadar air maksimal 14\%, beras kepala di atas $85 \%$, dan butir patah maksimal $15 \%$. Peraturan ini tertuang dalam Peraturan Menteri Pertanian Nomor 31 Tahun 2017. Jenis dan Kadar Beras Khusus berikut contoh produk beras khusus:

1. Beras Khusus Wangi:

- Thai Hom Mali (KDM105 \& RD15) 100\%

- Thai Hom Mali (KDML105 \& RD15) 5\%

2. Beras Khusus Basmati:

- India Pusa Basmati 1121 2\%

- India Pusa Basmati 2\%

- Pakistan Basmati Khainat2\%

3. Beras Khusus Hancur:

- Thailan Broken Rice 100\%

- Vietnam Broken Rice 100\%

- Pakistan Broken Rice 100\% 


\section{Merita Bernik}

\section{Mochammad Bima Ramadhan}

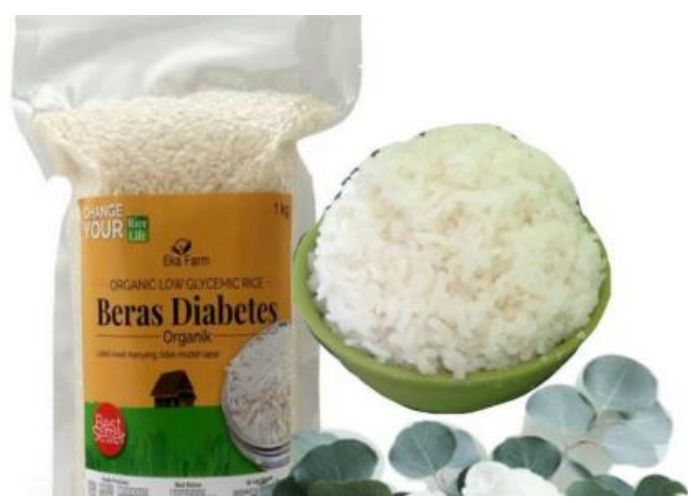

Gambar 3. Beras Khusus Wangi I

(Sumber: foto produk PT. Nazar Bahana Persada beras khusus wangi I tahun 2016)

Beras khusus Basmati beras yang mengandung derajat sosoh sama dengan beras premium $95 \%$, kadar air minimal 14\%, beras kepala di atas $15 \%$, dan butir patah maksimal $15 \%$.Beras khusus Basmati beras yang mengandung derajat sosoh sama dengan beras premium $95 \%$, kadar air minimal 14\%, beras kepala di atas 15\%, dan butir patah maksimal $15 \%$.

\section{Pelaksanaan Bauran Promosi pada PT Nazar Bahana Persada}

Sejak tahun 2017, bauran promosi yang dilaksanakan oleh PT Nazar Bahana Persada yaitu:

\section{Penjualan Perorangan(Personal Selling)}

PT. Nazar Bahana Persada menggunakan salah satu cara memasarkan produknya yang dilakukan secara langsung guna memudahkan berinteraksi langsung dengan konsumen. PT. Nazar Bahana Persada menggunakan bauran promosi personal selling ini bertujuan agarpara konsumen dapat memilih dan membeli produk dengan mudah dan terpercaya (Kesuma et al., 2015). Karena salah satu kelebihan menggunakan promosi personal selling dapat membuat pelanggan lebih bisa membandingkan produk, dan harga yang sesuai dengan kebutuhan pelanggan.

\section{Pemasaran Langsung (Direct Marketing)}

Pemasaran langsung yang dilakukan oleh PT. Nazar Bahana Persada agar produk yang dijual dapat berkembang lebih luas, dengan mendatangi daerah-daerah yang belum mengenal produk beras PT. Nazar Bahana Persada, produk yang dibuat PT. Nazar Bahana Persada seperti: beras medium, beras premium, dan beras khusus penyakit diabetes, produk tersebut dapat dijual secara langsung kepada masyarakat dan pihak lain, baik pemerintah maupun swasta.

Hasil pemasaran langsung (Direct marketing) menunjukkan bahwa PT. Nazar Bahana Persada juga dapat secara langsung menerima kerjasama dengan salah satu badan 
pemerintah yang mengelola penjualan beras. Target utama pemasaran langsung yang dilakukan oleh para marketing lebih banyak diarahkan kepada pemerintah, dan masyarakat.

\section{Periklanan (Advertising)}

Advertising adalah suatu penyajian materi atau pesan secara persuasif kepada masyarakat melalui media massa yang bertujuan untuk mempromosikan produk ataupun jasa yang dijual oleh perusahaan (Rahadian \& Pratomo, 2013).

PT. Nazar Bahana Persada membuat Company Profile sebagai bentuk Advertising perusahaan untuk disajikan kepada pelanggan yang ingin mengetahui tentang perusahaa. Company Profile \& sample produk tersebut berisi:

1. Surat Perkenalan perusahaan

2. Pengalaman Kerja Perusahaan

3. Surat Izin Usaha Perdagangan

4. NPWP Perusahaan dan Surat Pengukuhan Pengusaha Kena Pajak (PKP)

5. Tanda Daftar Perusahaan dan Surat Keterangan Domisili Perusahaan Adapun catalogue produk-produk perusahaan dalam Company Profile tersebut yang berisi spesifikasi produk tersebut diantaranya:

1. Beras Medium

2. Beras premium

3. Beras khusus penyakit diabetes

Pembuatan Company Profile PT. Nazar Bahana Persada dan juga produk yang tertera menunjukkan bahwa perusahaan ingin menyajikan sebuah pesan kepada pelanggan ataupun masyarakat untuk mempromosikan dan memperkenalkan produk hasil dari PT. Nazar Bahana Persada.

Public Relation melalui CSR (Corporate Social Responsibility)

Kegiatan lain yang juga merupakan promosi adalah pelaksanaan CSR (Corporate Social Responsibility) seperti pemotongan hewan qurban, dan pemberian parcel/paket hari raya lebaran untuk masyarakat sekitar, dan memberikan sumbangan beras untuk warga yang membutuhkan. Hal tersebut membentuk image baik dari masyarakat terhadap PT. Nazar Bahana Persada sebagai perusahaan yang memproduksi beras (Laraswati \& Deliyana, 2016). 


\section{Merita Bernik}

\section{Mochammad Bima Ramadhan}

\section{Dampak pelaksanaan bauran promosi terhadap omzet penjualan PT. Nazar Bahana Persada}

Pada tahun 2016 promosi yang dilaksanakan masih sederhana dalam bentuk personal selling, sedangkan pada tahun 2017 menggunakan 4 jenis bauran promosi. Hal tersebut mempengaruhi jumlah produk yang terjual dan juga besarnya jumlah penjualan, seperti pada data di bawah ini:

Tabel 2. Jumlah Produk yang Terjual dan Besarnya Penjualan tahun 2016-2017

\begin{tabular}{ccc}
\hline Tahun & Produk yang terjual & Omzet Penjualan (Rp) \\
\hline 2016 & 30,7 ton & 383.750 .000 \\
2017 & 44,44 ton & 577.200 .000 \\
\hline
\end{tabular}

(Sumber: PT. Nazar hasil omset keseluruhan tahun 2016-2017)

Berdasarkan data di atas, menunjukan bahwa jumlah penjualan produk tahun 2017 meningkat sebsar 44,75\% dibandingkan tahun 2016, sedangkan omzet penjualan tahun 2017 meningkat sebesar 50,41\% dibandingkan tahun 2016.

Pengujian mengenai dampak dari pelaksanaan bauran promosi pada tahun 2007 dibandingkan tahun 2016 dengan menggunakan Wilcoxon test (Tabel 2). Berdasarkan hasil test Wilcoxonmenunjukan bahwa Ho diterima dengan $Z$ hitung $<$ Z tabel, sehingga menunjukan bahwa omzet penjualan produk pada tahun 2017 setelah dilaksanakannya bauran promosi sama dengan omzet penjualan produk tahun 2016 yang hanya menggunakan 1 jenis promosi. Akan tetapi berdasarkan sum of positif rank sebesar $60>$ (lebih besar) daripada sum of negative ranks sebesar 18, yang menunjukan bahwa omzet penjualan tahun 2017 lebih banyak yang meningkat dibandingkan tahun 2016.

Tabel 2. Wilcoxon Signed Rank Test

\begin{tabular}{|c|c|}
\hline Variables & Group 1-Group 2 \\
\hline 60 & Sum of positive ranks \\
\hline 18 & Sum of negative ranks \\
\hline 12 & $\mathrm{n}$ \\
\hline 39,000 & Expected value \\
\hline 12,629 & Standart deviaton \\
\hline 1,663 & Z corrected for ties \\
\hline, 0964 & p-value (two-tailed) \\
\hline
\end{tabular}

Bauran promosi yang dilasanakan oleh PT. Nazar Bahan Persada pada tahun 2017 adalah penjualan perorangan, pemasaran langsung, periklanan dan CSR, sedangkan pada tahun 2016 hanya menggunakan penjualan peroarangan saja. Penambahan pelaksanaan bauran promosi tersebut bertujuan agar produk beras dari PT. Nazar Bahana Persada lebih 
dikenal dan diminati oleh konusmennya. Selain itu juga pelaksanaan bauran promosi tersebut diharapkan dapat meningkatkan omzet penjualan berasnya. Bauran promosi sangat penting untuk dilaksanakan oleh suatu perusahaan, seperti penelitian yang telah dilakukan oleh Mailliana dan Hayati (2016), dimana terbukti dengan melaksanakan 5 jenis bauran promosi berpengaruh terhadap peningkatan omzet penjulan.

Berdasarkan data penjualan produk beras tahun 2016-2017 ternyata mengalami peningkatan, begitu pula dengan omzet penjualan beras pada tahun 2017 mengalami peningkatan dibandingkan tahun 2016. Akan tetapi berdasarkan pengujian dengan menggunakan Wilcoxon tetst untuk mengetahui apakah memang bauran promosi yang dilaksanakan pada tahun 2017 tersebut memiliki dampak yang signifikan terhadap omzet penjualan, memperoleh hasil yang menunjukkan bahwa tidak terdapatnya perbedaan secara signifikan antara sebelum dan setelah dilaksanakannya 4 bauran promosi. Hasil penelitian yang dilaksanakn oleh Imelda dan Huwaida (2016) memberikan hasil yang sama dimana dengan menerapkan 4 jenis bauran promosi yaitu personal selling, promosi penjualan, periklanan dan publisitas ternyata kurang dapat memberikan dampak yang signifikan pada omzet penjulan.

Apabila dilihat dari jumlah rangking positifnya dimana menunjukkan bahwa omzet tahun 2017 meningkat dibandngkan omzet tahun 2016 lebih besar dibandingkan jumlah rangking negatifnya yang menunjukkan kebalikannya. Hal tersebut memberikan hasil yang menunjukkan bahwa walaupun tidak signifikannya dampak yang terjadi dari penerapan bauran promosi terhadap omzet penjualan, tetapi apabila dilihat secara rata-rata untuk setiap bulannya mengalami kenaikan.

\section{SIMPULAN DAN SARAN}

\section{Simpulan}

Berdasarkan hasil penelitian yang telah dilaksanakan, maka diperoleh kesimpulan sebagai berikut:

1. Produk beras dari PT Nazar Bahana Persada terdiri dari 3 janis yaitu beras medium, berap premium dan beras khusus, dimana setiap jenis produk beras tersebut memiliki ciri khasnya masing-masing.

2. Bauran promosi yang dilaksanakan pada tahun 2016 masih bersifat tradisional yaitu hanya menggunakan penjualan perseorangan, sedangkan tahun 2017 telah menerapkan 4 jenis bauran promosi yaitu penjualan perseorangan, pemasaran langsung, periklanan dan CSR.

3. Berdasarkan hasil pengujian dengan menggunakan Wilcoxon test, ternyata tidak terdapat perbedaan yang signifikan berdasarkan omzet penjualan sebelum dan 


\section{Merita Bernik}

\section{Mochammad Bima Ramadhan}

setelah dilakukan penambahan pelaksanaan bauran promosi, akan tetapi berdasarkan data omzet penjualan tahun 2017 dibandingkan tahun 2016 mengalami rata-rata kenaikan setiap bulannya, dengan kenaikan omzet penjualan sebesar $50,41 \%$, yang berarti terdapatnya dampak penerapan bauran pemasaran yang tadinya hanya dilaksanakan 1 jenis saja menjadi 4 jenia bauran promosi terhadap omzet penjualan. Begitu pula dengan banyaknya produk beras yang terjual tahun 2017 mengalami kenaikan sebesar 44,75\% dibandingkan tahun 2016, hal tersebut menunjukan semakin meningkatnya minat konsumen untuk membeli besar dari PT Nazar Bahana Persada

\section{Saran}

Adapun saran untuk penelitian selanjutnya dan bagi perusahaan adalah sebagai berikut:

1. Untuk melihat dampak yang lebih nyata dari pelaksanaan bauran promosi terhadap omzet penjualan, diperlukannya data yang lebih banyak, sehingga akan menunjukan hasil yang lebih signifikan lagi.

2. Perusahaan akan lebih baik lagi untuk menerapkan tidak hanya 4 jenis tetapi 6 jenis bauran promosi untuk dapat lebih meningkatkan jumlah produk yang terjual dan juga omzet penjualan. Media online dapat menjadi salah satu alternatif yang dapat dilakukan secara berkelanjutan, karena untuk melakukannya tidak diperlukan biaya yang besar dan juga dari segi pemasaran dapat menjangkau seluruh pelosok di Indonesia sehingga dapat memperluas pasar

\section{Daftar pustaka}

Lontoh, Michel N. 2016. Analisis Pengaruh Bauran Promosi Terhadap Keputusan Pembelian Mobil Toyota pada PT HasjratAbadi Manado Cbang Tandean. Jurnal Berkala IImiah Efisiensi, Vol 16 No 01.

Kotler, P. and Keller, Kevin Lane. 2016. Marketing Management, 15th Edition. United States Of America: Pearson.

Kennedy, John E. 2014. Marketing Communication : Taktik \& Strategi, Jakarta: PT. Bhuana IImu Populer.

Belch, George E and Belch, Michael A.2012. Advertising and Promotion, an Integrated Marketing Communication Persfective 10 th Edition, New York : McGraw-Hill. 
Cravens, David W and Piercy, Nigel F. 2013. Strategic Marketing, New York :McGraw-Hill.

Cummins, Julian and Mullin, Roddy. 2014. Sales Promotion, London and Philadelphia: Kogan Page.

Laksana, Fajar. 2013. Manajemen Pemasaran, Yogyakarta : Graha llmu.

Sakaran, Uma. 2012. Metodologi Penelitian untuk Bisnis 2, Jakarta: Salemba Empat.

Siegel, Sidney and N. Jhon Castellan Jr. 1988. Nonparametrics Statistics for Behavioral Science. Mc Grow Hill.

Kesuma, Jeffrey Andi, Budiono Karim dan bagus Qomaruzaman Ratu Edi. 2015. Pengaruh Bauran Promosi Terhadap Volume Penjualan Holcim Solusi Rumah Bintang Jaya di Jember. Jurnal Manajemen dan Bisnis Indonesia, Vol 1 No 2.

Rahadian, Dani dan Adythia Pratomo. 2013. Pengaruh Bauran Promosi Terhadap Peninngkatan Penjualan Kamar di Hotel Benua Bandung. Jurnal Binus Business Review, Vol 4 No. 2.

Laraswati, Dian Mutiyah dan Dina Dellyana. 2016. Analysis the Effect of Promotion Mix Strategy to Increase Sale on CosignmentSystem Toward Food and Baverage Star Up. The Journal of Innovation and Entrepreneurship, Vol 1 No. 1.

Mailliana dan Hayati, Diana. 2016. Pengaruh Bauran Promosi Terhadap Omzet Penjualan Produk Kerajinan Purun di Kabupaten Hulu Sungai Utara. Dinamika Ekonomi Jurnal Ekonomi dan Bisnis, vo 10 No. 1. 
Merita Bernik

Mochammad Bima Ramadhan

Imelda, Sri dan Huwaida, Hikmayanti. 2016. Strategi Promosi Guna Meningkatkan Omzet Penjualan Sparepart dan Service pada PT Nusantara Borneo Motor Banjarmasin. Jurnal Intekna, Vol 16 No 2. 